\title{
Metal artifact-free MRI-guided re-irradiation for recurrent spinal metastases from thyroid
} cancer

\author{
Reiradiace rekurentních spinálních metastáz karcinomu štítné \\ žlázy rrízená magnetickou rezonancí bez kovových artefaktů
}

\author{
Hama Y., Tate E. \\ Department of Radiation Oncology, Tokyo-Edogawa Cancer Centre, Edogawa Hospital, Tokyo, Japan
}

\begin{abstract}
Summary
Background: Soft tissue tumors near metal implants are sometimes difficult to treat with real-time image-guided radiation therapy. Low-field MRI was utilized to clearly delineate the tumor and spinal cord while avoiding metal artifacts, and re-irradiation was performed for recurrent spinal metastases. Case description: A 57-year-old woman with a history of thyroid cancer was referred for re-irradiation for recurrent painful bone metastases in the thoracolumbar spine. She had already undergone conventional radiation therapy followed by stereotactic ablative radiotherapy and multiple fusion surgeries. Since the radiation dose to the spinal cord should have been limited, metal artifact-free low-field MRI-guided re-irradiation was performed with no significant adverse events. Conclusion: Low-field MRI-guided re-irradiation may be feasible for recurrent spinal metastases, even after metal implants have been placed.
\end{abstract}

\section{Key words}

radiotherapy -intensity-modulated - image-guided - magnetic resonance imaging

\section{Souhrn}

Východiska: Léčba nádorů měkkých tkání pomocí obrazem řízené radioterapie v reálném čase je někdy obtížná. K jasnému vymezení nádoru a míchy byla použita MR bez kovových artefaktů s nízkou intenzitou magnetického pole a byla provedena reiradiace pro rekurentní spinální metastázy. Popis príipadu: 57letá žena s anamnézou karcinomu štítné žlázy byla odeslána na reiradiaci pro rekurentní bolestivé kostní metastázy v thorakolumbální oblasti páteře. Pacientka již podstoupila konvenční radioterapii, po které následovala stereotaktická ablační radioterapie a několik fúzních chirurgických zákroků. Jelikož radiační dávka na míchu je omezená, byla provedena reiradiace řizená MR bez kovových artefaktů s nízkou intenzitou magnetického pole, a sice bez významných nežádoucích účinků. Závěr: Reiradiace řízená MR s nízkou intenzitou magnetického pole je u rekurentních spinálních metastáz proveditelná, a to i v prítomnosti kovových implantátů.
The authors declare they have no potential conflicts of interest concerning drugs, products, or services used in the study.

Autor̆i deklarují, že $v$ souvislosti s predmětem studie nemaji žádné komerční zájmy.

The Editorial Board declares that the manuscript met the ICMJE recommendation for biomedical papers.

Redakční rada potvrzuje, že rukopis práce splnil ICMJE kritéria pro publikace zasílané do biomedicínských časopisů.

$\equiv$

Yukihiro Hama, MD, PhD

Department of Radiation Oncology, Tokyo-Edogawa Cancer Centre, Edogawa Hospital

2-24-18 Higashikoiwa, Edogawa

Tokyo, 133-0052

Japan

e-mail:yjhama2005@yahoo.co.jp

Submitted/Obdrženo: 24. 4. 2021

Accepted/Přijato: 14. 5. 2021

doi: $10.48095 /$ ccko2021401

\section{Klíčová slova}

radioterapie - s modulovanou intenzitou - obrazem řízená - magnetická rezonance 


\section{Introduction}

The prognosis for differentiated thyroid carcinoma (papillary or follicular) under 40 years is good, but distant metastases are one of the adverse prognostic factors [1-3]. Follicular thyroid cancer (FTC) tends to metastasize by hematogenous spread to distant sites, most commonly to the bones and lungs, and the spine is the most common site of bone metastases [4]. Since spinal metastases cause cord compression and paralysis, surgery and/or radiation therapy will be performed. However, even with surgery and radiation therapy, it is not always possible to completely control the tumor. In such a case, re-irradiation may be performed focusing only on the residual tumor. When re-irradiation is performed, the spinal cord and tumor must be clearly visualized in order to suppress the radiation dose to the spinal cord. Cone beam computed tomography (CBCT) or multi-detector row computed tomography (MDCT) for image-guided radiation therapy (IGRT) is suboptimal due to low tissue contrast and metal artifacts of the indwelling screws, plates, and rods after fixation surgery.

MRI provides clear visualization of spinal cord, tumor and bone, and may eliminate the limitations of CBCT or MDCT [5]. Higher field strengths will provide greater signal-to-noise ratio (SNR) and improve diagnostic accuracy than lower field strengths. Currently, the most common field strengths used in diagnostic imaging are 1.5T and 3.0T. However, higher field strengths produce larger susceptibility artifacts, and adjacent structures such as the spinal cord cannot be assessed accurately in the presence of metal implants.

Here we report a case of spinal metastasis treated by metal artifact-free MRI-guided re-irradiation after failure of surgical resection and conventional radiation therapy. By using a 0.35T low-field MRI, re-irradiation was safely performed under real-time MRI guidance.

\section{Case report}

A 57-year-old woman with a history of FTC was referred to our hospital for re-irradiation for recurrent painful bone metastases in the thoracic spine. She was diagnosed with metastatic FTC 7 years ago, underwent partial resection of the ninth thoracic spine (Th9), and underwent Th8-Th12 spinal fusion surgery. After spinal fusion surgery, total thyroidectomy and postoperative radioiodine (I-131) therapy was performed to ablate residual thyroid tissue and to treat occult cancer foci in the surgical bed and elsewhere. Despite a series of treatments, her thoracic spinal metastases worsened, so radiation therapy was performed using 2 ports in antero-posterior parallel opposed fields with a total dose of $44 \mathrm{~Gy}$ in 22 fractions. However, 2 years after radiation therapy, tumor re-growth was observed in the Th9 and Th12 vertebrae, so stereotactic ablative radiotherapy (SABR) was performed at doses of 24 Gy in 3 fractions and $8 \mathrm{~Gy}$ in a single fraction, respectively. Systemic chemotherapy with lenvatinib was tried twice, but could not be continued due to grade 4 vomiting and diarrhea. As the tumor in the lower thoracic spine grew gradually, the tumor in the $12^{\text {th }}$ thoracic vertebra was resected and posterior Th5-L1 fixation was performed using titanium screws and rods. Nevertheless, 10 months after reoperation, her serum thyroglobulin level increased to $1930 \mathrm{ng} / \mathrm{mL}$ (normal range: $0-32.7 \mathrm{ng} / \mathrm{mL}$ ), and the thoracolumbar spinal tumors (Th11-L1) grew again, causing severe pain and muscle weakness in both lower limbs. She had already had surgical resections twice and couldn't have any more, so she was to undergo radiation therapy.

Since she had already received conventional radiation therapy and subsequent SABR for her spinal metastases, the radiation dose to the spinal cord should have been limited to the lowest possible level. We initially tried to perform CT-guided intensity-modulated radiation therapy (IMRT), but CT scans could not be used to visualize the spinal cord due to metal artifacts (Fig. 1A) from the implanted metal devices (Fig. 1B). Megavoltage CT (MVCT) with $3.5 \mathrm{MV}$ Xrays in the helical tomotherapy machine (Hi ART, Madison, WI, USA) significantly reduced artifacts around the metal implants (Fig. 1C), but the tissue contrast was reduced and the spinal cord could not be visualized. In order to perform IGRT by visualizing both the tumor and the spinal cord, we attempted to create fusion images of MVCT and MRI. However, diagnostic MRI at 3T was unable to depict clearly the spinal cord due to susceptibility artifacts (Fig. 1D, E). In order to overcome these limitations, we decided to perform MRI-guided radiation therapy using a low-field 0.35T MRI-linac system (MRIdian Linac, ViewRay Inc., Oakwood, USA). All procedures were in accordance with the ethical standards of the institutional and/or national research committee and with the 1964 Helsinki Declaration and its later amendments or comparable ethical standards, and written informed consent was obtained from the patient. Since both the tumor and the spinal cord were clearly visualized by $0.35 \mathrm{~T} \mathrm{MRI} \mathrm{(Fig.} 1 \mathrm{~F}, \mathrm{G}$ ), it was possible to perform MRI-guided radiation therapy for the thoracolumbar spinal tumors.

The patient was laid in the supine position, and MRI-based radiation treatment planning was created using true fast imaging with steady-state precession (FISP) images. MRI-guided IMRT was performed using real-time trueFISP cine MRI with 30 Gy in 15 fractions (D95 of planning target volume (PTV)) over 3 weeks (Fig. 2). The maximum spinal cord dose was limited to 8 Gy but no limit was set on the maximum dose within the PTV. There were no grade 2 or higher adverse events during MRI-guided radiation therapy and at 3 months of follow-up.

\section{Discussion}

The enhanced visualization of anatomy by MRI not only facilitates dose escalation [5] but may also suppress the dose to the spinal cord. As far as we know, this is the first report of MRI-guided re-irradiation for recurrent spinal metastasis after multiple fixation surgeries. There are several advantages of low-field MRI-guided re-irradiation for spinal metastases after metal device placement.

First, low-field MRI can reduce susceptibility artifacts and chemical shift artifacts more than high-field (e.g., 1.5T, 3.0T) diagnostic MRI [6]. Susceptibility artifacts are distortions or local sig- 


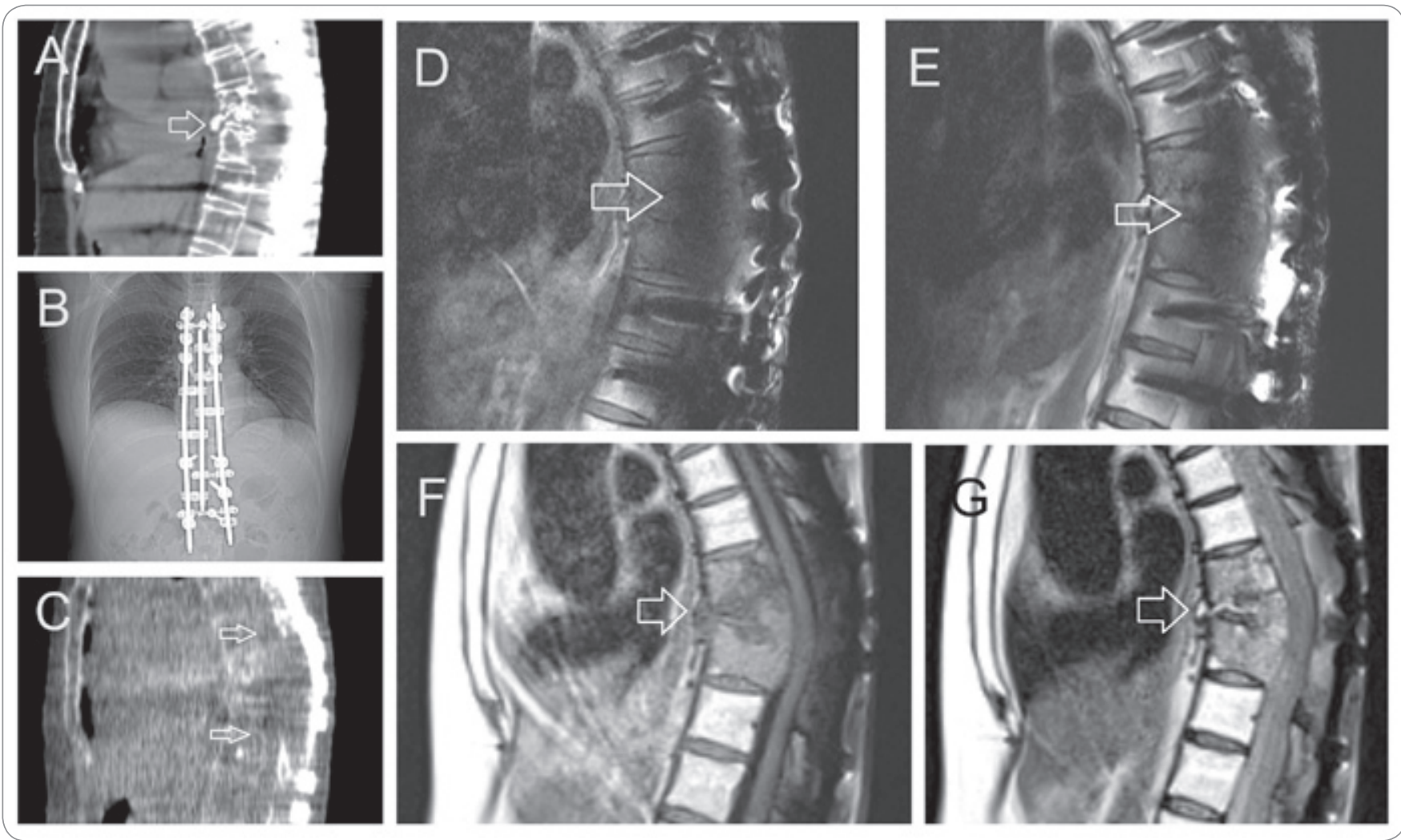

Fig. 1. A 57-year-old woman with recurrent spinal metastasis from thyroid cancer after surgical fixations and conventional radiation therapy. A) A sagittal reformatted CT scan of the thoracolumbar spine. The spinal cord is not clearly depicted due to metal artifacts. The 12th thoracic vertebra is resected (arrow) and osteolytic lesions can be seen in the 11th thoracic and the 1st lumbar vertebrae. B) Coronal scout CT shows multiple metal fusion devices. C) A sagittal reformatted megavoltage CT scan significantly reduced artifacts around the metal devices (arrows), but the soft-tissue contrast was reduced and the spinal cord could not be visualized. D) Sagittal T1-weighted turbo spin echo image of the thoracolumbar spine at 3T was unable to depict the spinal cord due to susceptibility artifacts (arrow) (repetition time/echo time $=550 \mathrm{msec} / 10 \mathrm{msec}$, flip angle $=150^{\circ}$, bandwidth $=280 \mathrm{~Hz}$, voxel size $=0.6 \times 0.6 \times 5.0 \mathrm{~mm}$, echo train length $=3$, field of view $=559 \times 559 \mathrm{~mm}$ ). E) Sagittal T2-weighted turbo spin echo image of the thoracolumbar spine at 3T was unable to depict the spinal cord due to susceptibility artifacts (arrow) (repetition time/echo time $=3,000 \mathrm{msec} / 90 \mathrm{msec}$, flip angle $=120^{\circ}$, bandwidth $=295 \mathrm{~Hz}$, voxel size $=0.6 \times 0.6 \times 5.0 \mathrm{~mm}$, echo train length $=24$, field of view $=559 \times 559 \mathrm{~mm}$ ). F) Sagittal T1-weighted turbo spin echo image of the thoracolumbar spine at $0.35 \mathrm{~T}$ clearly depicts the tumor (arrow) and the spinal cord (repetition time/echo time $=558 \mathrm{msec} /$ / $7.8 \mathrm{msec}$, flip angle $=120^{\circ}$, bandwidth $=296 \mathrm{~Hz}$, voxel size $=1.3 \times 1.3 \times 5.0 \mathrm{~mm}$, echo train length $=3$, field of view $=320 \times 320 \mathrm{~mm}$ ). G) Sagittal T2-weighted turbo spin echo image of the thoracolumbar spine at 0.35 T clearly depicts the tumor (arrow) and the spinal cord. (repetition time/echo time $=3,060 \mathrm{msec} / 78 \mathrm{msec}$, flip angle $=60^{\circ}$, bandwidth $=543 \mathrm{~Hz}$, voxel size $=1.4 \times 1.4 \times 5.0 \mathrm{~mm}$, echo train length $=1$, field of view $=292.5 \times 360 \mathrm{~mm}$ ).

nal changes due to local magnetic field inhomogeneities from metal devices. In the range of clinically available magnetic field strengths (0.2T-3.0T), the SNR increases in proportion to the main field, but susceptibility variation and chemical shift also increase in proportion to the main field. The field strength of $0.35 \mathrm{~T}$ is the optimal field strength to minimize susceptibility artifacts and chemical shift artifacts while maintaining the SNR required for IGRT.

Secondly, low-field MRI can significantly reduce the specific absorption rate (SAR) compared to high-field
MRI. Radio frequency (RF) field-induced heating of tissue near metal implants with real-time motion tracking is a concern for cine MRI in MRI-guided radiation therapy [7]. For true-FISP sequences with high gradient duty cycle, considerable heating of metal implants can be generated by gradient switching. In addition, under long imaging times like MRI-guided IMRT, the heating caused by gradient switching is expected to be greater. Since SAR is quadratically proportional to the field strength, SAR can be suppressed to about $1 / 100$ at $0.35 T$ as compared with 3T. With low-field MRI, real-time high soft tissue contrast trueFISP imaging can be used safely, even when the treatment time is long, such as IMRT.

Thirdly, there is no concern about electron return effect (ERE), where the secondary electrons in a magnetic field will move in a circular pattern due to the Lorentz force and enhance the dose at the interface between different density media. Dose enhancement by ERE is reported to be $30-40 \%$ in a $1.5 \mathrm{~T}$ MRI-linac system [8], whereas in low-field MRI system, no clinically problematic excessive dosage due to ERE has been reported. 


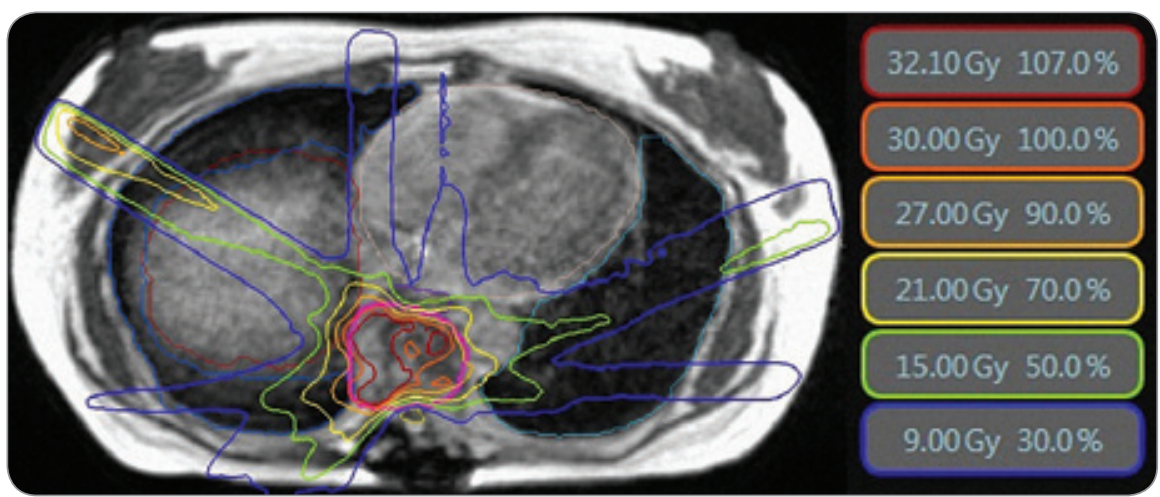

Fig. 2. Treatment planning axial MRI with isodose lines. The isodose lines are displayed on an axial true fast imaging with steady-state precession image. The maximum spinal cord dose was $7.8 \mathrm{~Gy}$ in 15 fractions.

There are several limitations in this study that could be addressed. First, the sequence parameters were not optimized for metal artifact reduction. Artifacts from metal implants include in-plane signal loss and pileup, absent fat suppression, geometric distortion, and through-section distortion [9]. If the metal artifact reduction sequences had been used, multiparametric higher resolution images of the metal implants would have been obtained [9]. However, at present, metal artifact reduction sequences are not available in the ViewRay system.

Secondly, the acquisition time is too long ( $\approx 5$ minutes for each scan) even taking into account that the MRI images were taken with a low-field MRI unit. Long acquisition time is a major obstacle to routine use for patients with spinal metastases. However, fast imaging techniques such as parallel imaging, non-Cartesian readout, partial k-space sampling, partial Fourier transform, view sharing, compressed sensing, and artificial intelligence-aided image reconstruction may overcome the obstacle.

\section{Conclusion}

In conclusion, a single case study cannot be generalized to others without further scientific verifications; however, metal artifact-free $\mathrm{MRI}$-guided re-irradiation using low-field MRI may be an effective treatment for recurrent spinal metastasis.

\section{References}

1. Shah JP, Loree TR, Dharker D et al. Prognostic factors in differentiated carcinoma of the thyroid gland. Am J Surg 1992; 164(6): 658-661. doi: 10.1016/s00029610(05)80729-9.

2. Filetti S, Durante C, Hartl D et al. Thyroid cancer: ESMO Clinical Practice Guidelines for diagnosis, treatment and follow-up. Ann Oncol 2019; 30(12): 1856-1883. doi: 10.1093/annonc/mdz400

3. National Cancer Institute. SEER stat fact sheets: thyroid cancer. [online]. Available from: https://seer.cancer. gov/statfacts/html/thyro.html.

4. Pal P, Singh B, Kane S et al. Bone metastases in follicular carcinoma of thyroid. Indian J Otolaryngol Head Neck Surg 2018; 70(1): 10-14. doi: 10.1007/s1 2070-017-1170-x. 5. Llorente R, Spieler BO, Victoria J et al. MRI-guided stereotactic ablative radiation therapy of spinal bone metastases: a preliminary experience. Br J Radiol 2020; 93(1105): 20190655. doi: 10.1259/bjr.20190655

6. Bernstein MA, Huston III J, Ward HA. Imaging artifacts at 3.0T. J Magn Reson Imaging 2006; 24(4): 735-746. doi: 10.1002/jmri.20698.

7. Graf H, Steidle G, Schick F. Heating of metallic implants and instruments induced by gradient switching in a 1.5Tesla whole-body unit. J Magn Reson Imaging 2007; 26(5): 1328-1333. doi: 10.1002/jmri.21157.

8. Raaijmakers AJE, Raaymakers BW, Lagendijk JJW. Integrating a MRI scanner with a $6 \mathrm{MV}$ radiotherapy accelerator: dose increase at tissue-air interfaces in a lateral magnetic field due to returning electrons. Phys Med Biol 2005; 50(7): 1363-1376. doi: 10.1088/0031-9155/50/7/002. 9. Talbot BS, Weinberg EP. MR imaging with metal-suppression sequences for evaluation of total joint arthroplasty. RadioGraphics 2016; 36: 209-225. doi: 10.1148/rg.2016150075. 